\title{
Effects of salinity stress on seedling biomass, physiochemical properties and grain yield in different breeding wheat genotypes
}

Alireza Pour-Aboghadareh ( $\nabla$ a.poraboghadareh@edu.ikiu.ac.ir)

Seed and Plant Improvement Institute https://orcid.org/0000-0001-5782-5327

Mohammad Reza Mehrvar

Seed and Plant Improvement Research Institute

Sara Sanjani

Seed and Plant Improvement Research Institute

Ashkboos Amini

Seed and Plant Improvement Research Institute

Hamidreza Nikkhah Chaman-Abad

Seed and Plant Improvement Research Institute

Ameneh Asadi

Seed and Plant Improvement Research Institute

\section{Research Article}

Keywords: Salinity stress, bread wheat, photosynthesis properties, Root-to-shoot $\mathrm{Na}+$ translocation, ranking pattern

Posted Date: March 8th, 2021

DOI: https://doi.org/10.21203/rs.3.rs-158975/v1

License: (a) (1) This work is licensed under a Creative Commons Attribution 4.0 International License. Read Full License 


\section{Abstract}

The salinity tolerance of 17 breeding wheat genotypes along with three local varieties was evaluated under control and salinity stress ( $160 \mathrm{mM}$ NaCl) conditions. At the seedling stage, shoot and root dry weights, relative water content (RWC), membrane stability index (MSI), relative chlorophyll content (SPAD index), root and shoot $\mathrm{Na}^{+}(\mathrm{RN}$ and $\mathrm{SN})$, root and shoot $\mathrm{K}^{+}$(RK and SK), root and shoot $\mathrm{K}^{+} / \mathrm{Na}^{+}$ratios (RKN and SKN), root-to-shoot Na+ translocation (RTSN), root-to-shoot $\mathrm{K}^{+}$translocation (RTSK), stomatal conductance $\left(G_{S}\right)$, transpiration rate $\left(T_{E}\right)$, and photosynthesis rate $\left(P_{N}\right)$ were measured. Moreover, the investigated genotypes were assessed in terms of grain yield across four saline regions during the 2018-2019 cropping seasons. Salinity stress caused a significant reduction in the RDW, SDW, PN, $G_{S}, T_{E}, \mathrm{SK}, \mathrm{RKN}, \mathrm{SKN}, \mathrm{RTSN}$, and RTSK, but resulted in increased RN, RK, and SN. The results of AMMI analysis of variance also indicated significant differences among test locations, genotypes, and their interaction effects. The PCA-based biplot revealed that grain yield strongly correlated with RKN and RK. Furthermore, the correlation among $P_{N}, G_{S}$, and $T_{E}$ traits was strong and positive and had a positive correlation with RWC, MSI, RDW, and SPAD index. Considering our results, RK and RKN were identified as useful physiological tools to screen salt tolerance at the early-growth stage. According to the ranking patterns obtained by the average sum of ranks method (ASR) and grain yield, we observed that genotype number G5 had considerable physiological potential at the early-growth stage and also responded well to soil salinity at the farm; thus this genotype can be promoted for commercial production.

\section{Introduction}

Salinity is one of the most important environmental stresses that negatively affect wheat productivity and furthermore contributes to food insecurity. Unfortunately, increased soil salinization in many regions worldwide caused by climate change and various human activities is progressively reducing agricultural productivity despite increasing food demand (Ahmadi et al. 2018; Isayenkov et al. 2019). Under salinity conditions, Na+ is the main toxic ion that induces both ionic toxicity and osmotic (Hagemann and Erdmann 1997). Thus, maintaining low concentrations of $\mathrm{Na}^{+}$is crucial for plant survival during salinity stress (Anil et al. 2007). Based on Munns's theory (1995), the response of plants to high salt levels of can be divided in two main phases, namely ion-independent (osmotic) and ion-dependent (ionic toxicity) phases. The osmotic phase initiates immediately after the accumulation of salts around the roots. The main consequence of this event is difficulty in extracting water from soil to roots, which ultimately reduces the rate of shoot growth. This situation reduces the mitigation of ion flux from root to shoot and closes the stomata (Hasegawa et al. 2000). The ionic toxicity phase, which occurs over days and even months, is related to the accumulation of cytotoxic ions (especially $\mathrm{Na}^{+}$) and is marked by reduction in plant metabolic processes, increased premature senescence, and finally cell death (Roy et al. 2014).

Salinity stress commonly induces many metabolic changes in plants, such as ion toxicity, induction of oxidative stress due to increased levels of reactive oxygen species (ROS), reduction in photosynthetic pigments and carbon assimilation, and decreased photosynthetic efficiency of photosystem II (Husain et al. 2003; Chen et al. 2016; Acosta-Motos et al. 2017). Plant tolerance to high concentrations of salts is a complex quantitative trait and all research thus far has focused on characterizing heritable tolerant variations and dissecting trait genetics (Liu et al. 2020). Therefore, many plant species have several important mechanisms that enable them to grow in saline conditions. Under salinity conditions, plants regulate stomatal conductance to decrease water loss through transpiration. In addition, partial stomatal closure may limit the photosynthetic rate, which results in enhancing ROS levels and maintaining or reducing plant growth and yield. Indeed, salinity creates an energy problem where the photosynthetic capacity of the plants is no longer able to provide the carbohydrate requirements of young leaves, which further decrease their growth (Dadshani et al. 2019).

Photosynthetic activity is a key physiochemical mechanism for identifying a salt-tolerant plant. Previously, Kawasaki et al. (2001) and Geilfus et al. (2015) reported the considerable genotypic variability of photosynthetic activity and its related traits in several rice and fava bean genotypes, respectively. Panwar et al. (2016) also noted that chlorophyll content can be used as a useful index to determine the tolerance level in wheat. Intercellular ion regulation is an important physiological mechanism for salinity tolerance. This mechanism includes reducing the uptake of $\mathrm{Na}^{+}$into the root or excluding $\mathrm{Na}^{+}$from root and shoot, minimizing salt concentration in the cytosol, and partitioning of $\mathrm{Na}^{+}$into various tissues or cells (Arzani and Ashraf 2016). In recent years, research was mainly focused on maintenance of $\mathrm{Na}^{+} / \mathrm{K}^{+}$ratio as the main mechanism for salinity tolerance (Dadshani et al. 2019). Ahmadi et al. (2018) evaluated a core collection of wheat germplasm with contrasting salt tolerance and reported that the ability of wheat accessions to retain $\mathrm{K}^{+}$ under salt stress was critical for their salt tolerance.

Bread wheat (Triticum aestivum L.) is an important cereal crop grown throughout most regions in the world. Its yield is affected by various environmental stresses, particularly drought and salinity (Maghsoudi et al. 2016). The global production volume of wheat is 763 million tones (FAO 2020 ) and supports $20 \%$ of the daily calories and protein requirement for 4.5 billion people worldwide (Singh et al. 2020). However, this crop suffers from considerable yield losses due to different biotic and abiotic stresses. Although wheat is moderately tolerant to salinity stress, up to $40 \%$ crop yield losses have been reported in salt-affected areas (Qadir et al. 2014). Numerous studies have shown the effects of salt stress on different wheat genotypes, among which some are salt tolerant and some susceptible. In wheat, higher salt concentrations in soil or irrigation water dramatically decrease germination rate, photosynthesis, and transpiration and increase accumulation of $\mathrm{Na}^{+}$and $\mathrm{Cl}^{-}$ions, which in turn disturb normal metabolic processes (Hasanuzzaman et al. 2017). Salt stress significantly affects the growth of wheat seedlings. Several traits such as root and shoot biomass, plant height, number of fertile tillers, number of spikes, and kernel weight are considered as growth parameters. In the seedling stage, wheat plants are more sensitive to saline conditions, thus high salinity may cause death of seedlings. Fresh and dry biomasses of shoot and root, leaf area, relative water content, photosynthetic pigment concentrations, among other parameters, of both tolerant and sensitive genotypes decline under salt stress in wheat seedlings (Arfan et al. 2007). Several studies revealed that fresh and dry weights of both roots and shoots of wheat seedlings were negatively affected by different levels of salinity (Athar et al. 
2007; Afzal et al. 2008; Ghiyasi et al. 2008; Akbarimoghaddam et al. 2011). Reduction of photosynthetic processes and its related parameters under salinity conditions were also reported by Guo et al. (2015), Zou et al. (2016), and Ahmadi et al. (2020).

Genetic variability is a basic component for efficient breeding of salinity tolerance in wheat. Improvement of wheat varieties with high adaptation to saline environments through use of local varieties or wild relatives in breeding programs is a widely accepted strategy to overcome the genetic bottleneck imposed by domestication and modern breeding programs (Nevo and Chen 2010). Bread wheat is the main crop cultivated in Iran as a staple food. In Iran, approximately 6.5 Mha of croplands are affected by varying degrees of salinity, which damages crop ecosystems (Agricultural Planning Economic and Rural Development Research Institute (APERDRI), 2020). Based on the Stanford Iran 2040 Project report, many parts of country are located in arid areas with $>70 \%$ annual aridity index. Thus, wide areas of this country will encounter serious problems due to soil salinization in the near future. Therefore, development of new salt-tolerant varieties of wheat and increasing the area under cultivation of these varieties can help agricultural productivity. Nearly 3 decades of effort towards improvement of wheat salinity tolerance have been invested in Iran, and thus far several commercial cultivars such as Narin, Bam, Arg, Sistan, and Barzegar have been introduced to farmers for use in saline regions. Here, we tested a set of new advanced wheat lines to determine if genetic variability exists among breeding genotypes for salinity tolerance in terms of physiological traits and grain yield and if a logical relationship among measured physiological traits exists at the seedling stage and grain yield at the end-of-life period of a wheat plant. Hence, the present study was planned such to evaluate the 17 new breeding genotypes obtained from national breeding program crosses among Iranian local and foreign cultivars in terms of physiological traits and to identify superior genotypes that can be utilized for peer screening and to breed salt-tolerant wheat varieties.

\section{Materials And Methods Plant materials}

A set of 17 breeding lines from different crosses among Iranian local cultivars along with three control varieties (cv. Narin, Sistan, and Barzegar as the tolerant control) were tested under control and severe salinity stress conditions. Additional information on the pedigrees is found in Supplementary Table 1 .

\section{Glasshouse experiment setup}

A glasshouse experiment was performed in 2019-2020 at the Cereal Research Department, Seed and Plant Improvement Institute (SPII), Karaj, Iran. All genotypes were grown in a hydroponic system at an optimal growing photoperiod ( $16 \mathrm{~h}$ light, $8 \mathrm{~h} \mathrm{dark})$ and temperature $\left(25^{\circ} \mathrm{C}\right.$ day, $20 \pm 2{ }^{\circ} \mathrm{C}$ night). Plant materials were sowed on planting trays. All planting trays were placed into tanks filled with $20 \mathrm{~L}$ of Hoagland nutrient solution (consisting of $\left(\mathrm{NH}_{4}\right) \mathrm{H}_{2} \mathrm{PO}_{4}$ $\left(115 \mathrm{~g} \mathrm{~L}^{-1}\right), \mathrm{KNO}_{3}\left(107 \mathrm{~g} \mathrm{~L}^{-1}\right), \mathrm{Ca}\left(\mathrm{NO}_{3}\right)_{2} \cdot 4 \mathrm{H}_{2} \mathrm{O}\left(236 \mathrm{~g} \mathrm{~L}^{-1}\right), \mathrm{MgSO}_{4} .7 \mathrm{H}_{2} \mathrm{O}\left(246 \mathrm{~g} \mathrm{~L}^{-1}\right)$, Fe-EDTA $\left(5 \mathrm{~g} \mathrm{~L}^{-1}\right), \mathrm{H}_{3} \mathrm{BO}_{3}\left(0.38 \mathrm{~g} \mathrm{~L}^{-1}\right), \mathrm{ZnSO}_{4} .7 \mathrm{H}_{2} \mathrm{O}\left(0.22 \mathrm{~g} \mathrm{~L}^{-1}\right)$, $\mathrm{MnSO}_{4} \cdot 4 \mathrm{H}_{2} \mathrm{O}\left(1.02 \mathrm{~g} \mathrm{~L}^{-1}\right)$, $\mathrm{CuSO}_{4} \cdot 5 \mathrm{H}_{2} \mathrm{O}\left(0.08 \mathrm{~g} \mathrm{~L}^{-1}\right)$, and $\left(\mathrm{NH}_{4}\right)_{6} \mathrm{MO}_{7} \cdot \mathrm{O}_{24} \cdot 4 \mathrm{H}_{2} \mathrm{O}\left(0.02 \mathrm{~g} \mathrm{~L}^{-1}\right)$ (Hoagland and Arnon 1950). Two separated experiments were performed based on a randomized block design with three replications. The stress treatments consisted of two control ( $0 \mathrm{mM} \mathrm{NaCl})$ and salinity $(160 \mathrm{mM} \mathrm{NaCl})$ conditions. Nutrient solutions were changed every 2 days. Aeration was supplied to each tank with a central air pump and two large airstones. The aeration was switched on 24 hours after planting. At the third-leaf stage, salinity stress was commenced by adding $\mathrm{NaCl}$ in five steps to reach $160 \mathrm{mM} \mathrm{(} 16 \mathrm{dS} \mathrm{m}^{-1}$ ) (Oyiga et al. 2016; Rahnama et al. 2019). Control seedlings (non-stressed) only received nutrient solution. Several physiological traits were measured after 21 days of salinity treatment.

The root and shoot dry weights (RDW and SDW, respectively) were determined by oven-drying of the root and shoot tissues at $70^{\circ} \mathrm{C}$ for 48 hours. The leaf samples of each genotype were used to measure the water relative content (RWC). This parameter was recorded using the following relation (Blum 2010):

RWC $\%=[$ fresh weight - dry weight $] /$ [turgid weight - dry weight $] \times 100$

The relative chlorophyll content was estimated using a handheld chlorophyll meter (Minolta SPAD-502, Tokyo, Japan). To measure leaf gas exchange, a clean and healthy leaf from each genotype was selected. The net photosynthetic rate $\left(P_{N}\right)$, stomatal conductance $(G s)$, and transpiration rate $\left(T_{E}\right)$ were measured on a developed leaf using an infrared gas analyzer (LICOR, Lincoln, USA). All measurements were recorded between 9 AM and 3 PM at a fixed flow rate of $400 \mu \mathrm{mol} \mathrm{s}^{-1}$. During the measuring of traits, light intensity was fixed from 800 to $1800 \mathrm{~lx}$.

The leaf samples were also used for a membrane stability index (MSI) assay according to Sairam et al. (2002). Briefly, leaf samples (0.1 g) were cut and placed in tubes containing $10 \mathrm{ml}$ of double-distilled water in two separate sets. One set was maintained at $40^{\circ} \mathrm{C}$ for 30 minutes and another set at $100^{\circ} \mathrm{C}$ for 15 minutes in a boiling water bath. The electronic conductivity of each set (C1 and C2, respectively) was measured by a conductivity meter (AQUALYTIC, Germany) and MSI was then determined by the following equation:

\section{$\mathrm{MSI}=[1-(\mathrm{C} 1 / \mathrm{C} 2)] \times 100$}

Root and shoot samples $\left(10 \mathrm{mg}\right.$ ) were digested with $10 \mathrm{ml} 0.5 \mathrm{~N}$ nitric acid and kept at $85^{\circ} \mathrm{C}$ for 2 hours in a boiling water bath. The digested plant material was filtered and analyzed for $\mathrm{Na}^{+}$and $\mathrm{K}^{+}$concentrations ( $\mathrm{mmol} \mathrm{g}{ }^{-1}$ dry weight (DW)) using flame photometry (Sherwood Scientific Flame Photometer 420, UK). Using these data, the $\mathrm{Na}^{+}$and $\mathrm{K}^{+}$translocation from roots to shoots were estimated following the method of Saqib et al. (2005) using the formulae below: 
Root-to-shoot $\mathrm{K}^{+}$translocation $(\mathrm{RTSK})=\left[\right.$ shoot $\mathrm{K}^{+}$content $(\mathrm{mmol}) / \operatorname{root} \mathrm{K}^{+}$content $\left.(\mathrm{mmol})\right]$ Field experiment trials

The multi-location trials were performed at four saline regions of Iran (Yazd, Birjand, Esfahan, and Kerman) during the 2018-2019 cropping season. In all sites, the salinity level of soil and irrigation water were tested during the experimental period from seed sowing to harvesting. The mean salinity of soil and irrigation water was 12 and $10 \mathrm{dS} \mathrm{m}^{-1}$, respectively. Fertilizer treatments of $100 \mathrm{~kg} \mathrm{P}_{2} \mathrm{O}_{5} \mathrm{ha}^{-1}$ and $32 \mathrm{~kg} \mathrm{~N}^{-1}$ were applied to the soil at the planting stage in each experiment. At each research station, genotypes were planted in a randomized complete block design with four replications. Each plot included eight 2.5-m-long rows with intra-row spacing of $0.15 \mathrm{~m}$. Sowing was performed by an experimental plot planter (Wintersteiger, Austria) with a plant density of 450 seeds per square meter. The trials were kept weed-free by applying Puma-super (Fenoxaprop-p-ethyl) and Granstar (Tribenuron methyl DF-75\%) as a foliar contact and pre-emergence herbicides. At harvest time, plots were harvested using experimental combine (Wintersteiger, Austria). Finally, grain yields were measured and data were converted to tonnes per hectare.

\section{Statistical data analysis}

In the glasshouse experiment, a combined analysis of variance (ANOVA) was computed to test the effects of main factors (environment [control and salinity] and genotype) and their interaction. The relative change (RC) due to salinity stress was computed for each trait using the following equation:

$\mathrm{RC} \%=\left[\left(\mathrm{X}_{\text {control }}-\mathrm{X}_{\text {stress }}\right) /\left(\mathrm{X}_{\text {control }}\right)\right] \times 100$

where $\mathrm{X}_{\text {control }}$ and $\mathrm{X}_{\text {stress }}$ are the values of a trait in a given genotype under control and salinity conditions, respectively.

In the field experiment trials, the grain yield data of the 20 investigated bread wheat genotypes were subjected to the additive main effects and multiplicative interaction (AMMI) analysis as proposed by Zobel et al. (1988) using GenStat software (GENSTAT 2008). Differences among the environment and genotype means were tested using Duncan's multiple range test. Principal component analysis (PCA) using the measurements recorded at the seedling stage and grain yield was computed using XLSTAT software (XLSTAT, Addisonsoft, Paris France). The ranking method was employed to select the ideal genotype(s) through measured traits and grain yield according to the approach described by Ketata et al. (1989). According to this method, the average of sum of ranks (ASR) was used as an index to identify the tolerant genotypes. In other words, the best value of each trait received the minimum rank and thus the genotypes with the lowest ASR values were recognized as the best genotypes. Additionally, relationships among the measured traits at seedling stage and grain yield obtained from multi-environment trials was tested by Pearson's correlation.

\section{Results}

\section{Root and shoot biomasses, leaf RWC and MSI}

Under control and salinity stress conditions, the tested bread wheat genotypes significantly differed with respect to root and shoot biomasses, RWC, and MSI traits. Salinity stress also significantly affected these parameters. However, the interaction effect between salinity stress and genotypes was not significant for all of these parameters (Table 1). Under salinity stress, the mean of RDW, SDW, RWC, and MSI for the 20 tested genotypes decreased by $24.44 \%, 49.98 \%, 3.38 \%$, and $3.79 \%$, respectively, compared with their respective values in control conditions. Under control conditions, RDW ranged from 0.08 to $0.21 \mathrm{~g} \mathrm{plant}^{-1}$ with an average of $0.14 \mathrm{~g} \mathrm{plant}^{-1}$, and genotypes $\mathrm{G} 7, \mathrm{G} 10$, and $\mathrm{G} 11$ had the highest values (Table 2). Under salinity conditions, RDW varied between 0.08 and $0.15 \mathrm{~g} \mathrm{plant}^{-1}$ with a mean of $0.11 \mathrm{~g} \mathrm{plant}^{-1}$, and the control variety $\mathrm{G} 2$ followed by G14, G15, and G17 had the highest

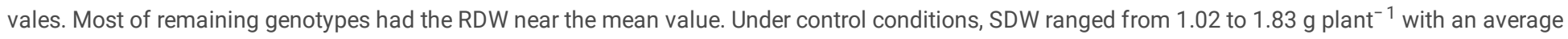
of $1.24 \mathrm{~g} \mathrm{plant}^{-1}$, and genotypes G3, G5, and G20 had the highest amounts. Under salinity conditions, SDW ranged from 0.51 to $0.91 \mathrm{~g}$ plant ${ }^{-1}$ with an average of $0.62 \mathrm{~g} \mathrm{plant}^{-1}$. The highest SDW values were recorded for G3, G17, and G20, while genotypes G7, G8 and G9 produced the lowest shoot biomass. 
Table 1

Analysis of variance (mean squares) of the measured traits in 20 bread wheat genotypes under control and salinity stress conditions

\begin{tabular}{|c|c|c|c|c|c|}
\hline Traits & Salt treatment $(S ; d f=2)$ & Replication/S $(d f=4)$ & Genotype (G; $d f=19)$ & $\begin{array}{l}G \times S \\
(d f=19)\end{array}$ & $\begin{array}{l}\text { Error } \\
(\mathrm{df}=76)\end{array}$ \\
\hline Relative chlorophyll content (SPAD) & $8.64^{\mathrm{ns}}$ & 9.51 & $19.51^{\star \star}$ & $2.08^{n s}$ & 5.38 \\
\hline Relative water content (RWC) & $289.6^{\mathrm{ns}}$ & 99.96 & $36.12^{\star \star}$ & $6.09^{n s}$ & 9.37 \\
\hline Root dry weight (RDW) & $0.037^{\star \star}$ & 0.001 & $0.002^{\mathrm{ns}}$ & $0.003^{n s}$ & 0.003 \\
\hline Photosynthetic rate $\left(P_{N}\right)$ & $5521.63^{\text {ns }}$ & 1461.05 & $120.65^{\star}$ & $54.5^{\mathrm{ns}}$ & 72.89 \\
\hline Stomatal conductance $\left(G_{S}\right)$ & $0.001^{\star \star \star}$ & 0.004 & $0.003^{*}$ & $0.0001^{\mathrm{ns}}$ & 0.0001 \\
\hline Transpiration rate $\left(T_{E}\right)$ & $1.25^{\mathrm{ns}}$ & 26.54 & $1.75^{\star *}$ & $0.72^{\mathrm{ns}}$ & 0.678 \\
\hline Root $\mathrm{K}^{+}$content (RK) & $21.03^{*}$ & 8.44 & $4.21^{\mathrm{ns}}$ & $3.82^{\text {ns }}$ & 3.4 \\
\hline Shoot $\mathrm{Na}^{+}$content $(\mathrm{SN})$ & $196.18^{\star \star \star}$ & 32.43 & $24.64^{\star \star}$ & $17.69^{\star \star}$ & 7.43 \\
\hline Shoot $\mathrm{K}^{+}$content (SK) & $24.96^{\star \star \star}$ & 6.99 & $2.33^{\text {ns }}$ & $0.74^{\mathrm{ns}}$ & 1.81 \\
\hline Root K+/Na + ratio (RKN) & $192.67^{\star \star \star}$ & 5.09 & $1.28^{\mathrm{ns}}$ & $1.24^{\mathrm{ns}}$ & 1.59 \\
\hline Shoot $\mathrm{K}+/ \mathrm{Na}+$ ratio $(\mathrm{SKN})$ & $5.04^{\star \star \star}$ & 0.68 & $0.28^{*}$ & $0.16^{\mathrm{ns}}$ & 0.17 \\
\hline Root-to-shoot $\mathrm{Na}^{+}$translocation (RTSN) & $543.11^{\star \star \star}$ & 0.69 & $5.17^{\star}$ & $4.45^{*}$ & 2.42 \\
\hline Root-to-shoot $\mathrm{K}^{+}$translocation (RTSK) & $12.37^{\star \star}$ & 0.38 & $3.45^{\star}$ & $1.98^{\mathrm{ns}}$ & 2.11 \\
\hline
\end{tabular}


Table 2

Mean values of dry biomass and physiological traits in the 20 bread wheat genotypes under control and salinity stress conditions

\begin{tabular}{|c|c|c|c|c|c|c|c|c|c|c|c|c|c|c|c|c|}
\hline \multirow{2}{*}{$\begin{array}{l}\text { Genotype } \\
\text { code }\end{array}$} & \multicolumn{2}{|l|}{ RDW } & \multicolumn{2}{|l|}{ SDW } & \multicolumn{2}{|l|}{ SPAD } & \multicolumn{2}{|l|}{$P_{N}$} & \multicolumn{2}{|l|}{$G_{S}$} & \multicolumn{2}{|l|}{$T_{E}$} & \multicolumn{2}{|l|}{ MSI } & \multicolumn{2}{|l|}{ RWC } \\
\hline & ${ }^{+} \mathrm{C}$ & $S$ & C & $S$ & $C$ & $S$ & $C$ & $S$ & $C$ & $S$ & $C$ & $S$ & $C$ & $S$ & $C$ & $S$ \\
\hline G1 & 0.16 & 0.11 & 1.18 & 0.59 & 36.00 & 33.87 & 32.47 & 21.27 & 0.023 & 0.001 & 1.41 & 0.33 & 91.59 & 92.67 & 91.18 & 87.53 \\
\hline $\mathrm{G} 2$ & 0.13 & 0.15 & 1.14 & 0.57 & 33.83 & 32.83 & 39.93 & 21.33 & 0.017 & 0.011 & 0.86 & 1.31 & 95.73 & 93.20 & 92.05 & 86.80 \\
\hline G3 & 0.16 & 0.11 & 1.83 & 0.91 & 32.87 & 32.27 & 36.63 & 21.70 & 0.030 & 0.005 & 1.71 & 0.32 & 97.72 & 85.01 & 90.26 & 85.19 \\
\hline G4 & 0.15 & 0.11 & 1.20 & 0.60 & 33.07 & 32.87 & 38.97 & 25.07 & 0.026 & 0.004 & 1.07 & 0.58 & 92.73 & 92.08 & 94.35 & 92.27 \\
\hline G5 & 0.17 & 0.09 & 1.33 & 0.67 & 30.87 & 32.13 & 47.57 & 26.67 & 0.016 & 0.010 & 1.47 & 0.88 & 93.53 & 90.60 & 91.21 & 85.90 \\
\hline G6 & 0.13 & 0.09 & 1.14 & 0.57 & 33.97 & 32.30 & 40.63 & 29.57 & 0.020 & 0.010 & 1.47 & 1.02 & 92.29 & 91.03 & 91.20 & 85.67 \\
\hline G7 & 0.20 & 0.10 & 1.02 & 0.51 & 30.77 & 29.93 & 40.73 & 26.23 & 0.009 & 0.008 & 0.58 & 0.59 & 93.65 & 65.67 & 91.28 & 86.98 \\
\hline G8 & 0.13 & 0.08 & 1.04 & 0.52 & 32.90 & 31.50 & 53.37 & 34.83 & 0.023 & 0.024 & 1.71 & 2.37 & 96.03 & 82.99 & 89.92 & 88.91 \\
\hline G9 & 0.13 & 0.10 & 1.06 & 0.53 & 29.80 & 31.40 & 35.87 & 35.77 & 0.015 & 0.006 & 0.94 & 0.37 & 95.13 & 90.53 & 88.67 & 84.65 \\
\hline G10 & 0.19 & 0.12 & 1.29 & 0.64 & 31.60 & 31.40 & 48.23 & 38.67 & 0.021 & 0.008 & 1.55 & 0.47 & 95.96 & 93.45 & 94.22 & 87.78 \\
\hline G11 & 0.21 & 0.09 & 1.24 & 0.62 & 31.33 & 31.63 & 43.00 & 23.77 & 0.040 & 0.023 & 2.26 & 2.33 & 92.64 & 89.52 & 88.36 & 87.15 \\
\hline G12 & 0.13 & 0.10 & 1.25 & 0.63 & 31.67 & 29.30 & 38.87 & 21.23 & 0.033 & 0.019 & 1.09 & 1.90 & 95.40 & 94.50 & 89.72 & 86.69 \\
\hline G13 & 0.13 & 0.10 & 1.27 & 0.64 & 33.07 & 34.03 & 47.40 & 25.67 & 0.020 & 0.016 & 1.27 & 1.54 & 94.16 & 90.40 & 90.52 & 86.71 \\
\hline G14 & 0.15 & 0.14 & 1.07 & 0.53 & 33.60 & 32.70 & 42.33 & 34.60 & 0.030 & 0.027 & 1.57 & 2.64 & 92.91 & 92.51 & 93.43 & 90.94 \\
\hline G15 & 0.10 & 0.14 & 1.26 & 0.63 & 35.37 & 33.67 & 39.30 & 26.17 & 0.019 & 0.011 & 0.78 & 0.59 & 93.31 & 91.21 & 95.35 & 95.10 \\
\hline G16 & 0.12 & 0.09 & 1.09 & 0.55 & 37.13 & 36.60 & 43.10 & 35.70 & 0.037 & 0.023 & 2.19 & 2.25 & 94.94 & 90.50 & 93.24 & 93.28 \\
\hline G17 & 0.09 & 0.14 & 1.29 & 0.64 & 37.13 & 35.47 & 46.57 & 28.90 & 0.024 & 0.027 & 1.71 & 2.26 & 94.85 & 96.29 & 93.30 & 93.60 \\
\hline G18 & 0.14 & 0.11 & 1.25 & 0.63 & 32.87 & 33.03 & 40.53 & 33.77 & 0.024 & 0.017 & 1.78 & 1.26 & 92.66 & 95.01 & 95.61 & 91.41 \\
\hline G19 & 0.15 & 0.09 & 1.26 & 0.63 & 32.23 & 31.07 & 49.67 & 28.43 & 0.030 & 0.011 & 1.62 & 0.79 & 90.26 & 90.37 & 92.78 & 91.54 \\
\hline G20 & 0.13 & 0.13 & 1.52 & 0.76 & 33.37 & 34.70 & 38.87 & 33.37 & 0.028 & 0.006 & 1.59 & 0.74 & 89.05 & 95.80 & 91.25 & 87.67 \\
\hline Mean & 0.14 & 0.11 & 1.24 & 0.62 & 33.17 & 32.64 & 42.20 & 28.64 & 0.024 & 0.013 & 1.43 & 1.23 & 93.73 & 90.17 & 91.89 & 88.79 \\
\hline Std. & 0.006 & 0.005 & 0.03 & 0.02 & 0.37 & 0.31 & 1.51 & 1.37 & 0.002 & 0.001 & 0.19 & 0.13 & 0.46 & 1.54 & 0.36 & 0.63 \\
\hline${ }^{\ddagger} \mathrm{RC}(\%)$ & 24.44 & & 49.98 & & 1.62 & & 32.15 & & 44.63 & & 14.25 & & 3.80 & & 3.38 & \\
\hline \multicolumn{17}{|c|}{ 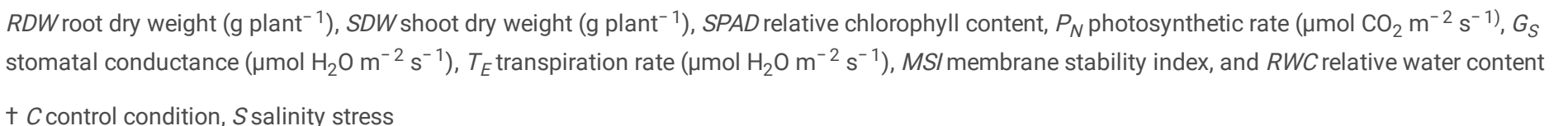 } \\
\hline
\end{tabular}

RWC varied between $88.36 \%$ and $95.61 \%$ in control conditions and from $84.65-95.10 \%$ in the salinity condition. The highest values for this trait in the control/salinity conditions were recorded for genotypes G10/G15, G15/G16, and G18/G17. Unlike other traits, MSI had a low variability in both the control and salinity conditions, ranging from $89.05-97.72 \%$ in the control and $82.99-96.29 \%$ in the salinity condition. Genotypes G8 and G10, along with the control variety G3, showed the highest MSI in the control and G17, G18, and G20 in the salinity condition (Table 2).

\section{Chlorophyll content, $P_{N}, G_{S}$ and $T_{E}$}

ANOVA indicated that salinity stress significantly affected $P_{N}$ and $G_{S}$ among genotypes. However, significant differences for relative chlorophyll content (SPAD index), $P_{N}, G_{S}$ and $T_{E}$ were observed among the tested genotypes. The interaction effect between salinity treatments and genotype was not significant for all traits (Table 1). Salinity stress caused a $1.62 \%$ reduction in relative chlorophyll content compared to the control (range $29.80-37.13$, average 33.17 in the control, range 29.93-36.60 with average 32.63 in the stress condition) (Table 2). Under control conditions, genotypes G16 and G17 and the control variety $\mathrm{G} 1$ had the highest SPAD index, whereas the highest values in the stress condition was recorded for G16, G17, and G20.

The pattern changes of data in tested genotypes showed that salinity stress caused a $32.15 \%$ decline in $P_{N}$ compared to control conditions. This trait ranged from 32.47 to $53.37 \mu \mathrm{mol} \mathrm{CO} \mathrm{m}^{-2} \mathrm{~s}^{-1}$ with an average of 42.20 in the control and from 21.23 to $38.67 \mu \mathrm{mol} \mathrm{CO} 2 \mathrm{~m}^{-2} \mathrm{~s}^{-1}$ with an average of 
$28.64 \mu \mathrm{mol} \mathrm{CO} \mathrm{C}_{2} \mathrm{~m}^{-2} \mathrm{~s}^{-1}$ in stress conditions. Genotypes $\mathrm{G} 8, \mathrm{G} 10$, and $\mathrm{G} 19$ in the control and G9, G10, and G16 in stress conditions were identified as the best genotypes with a high rate of $P_{N}$ compared with other genotypes (Table 2 ). Salinity stress considerably affected $G_{S}$, which decreased by $44.63 \%$ across the 20 genotypes from $0.024 \mu \mathrm{mol} \mathrm{H} \mathrm{H}_{2} \mathrm{~m}^{-2} \mathrm{~s}^{-1}$ in the control to $0.013 \mu \mathrm{mol} \mathrm{H}_{2} \mathrm{O} \mathrm{m}^{-2} \mathrm{~s}^{-1}$ under salinity stress conditions (Table 2). Under control conditions, the highest $G_{S}$ values were recorded for genotypes G11, G12, and G16. Under stress conditions, G8, G14, and G16 had the highest stomatal conductance than others (Table 2). Salinity stress significantly decreased $T_{E}$ (approximately $15 \%$ ) compared with control conditions (Table 2). Under control conditions, $T_{E}$ varied between 0.78 and $2.26 \mu \mathrm{mol} \mathrm{H} \mathrm{H}_{2} \mathrm{~m}^{-2} \mathrm{~s}^{-1}$ with an average of $1.43 \mu \mathrm{mol} \mathrm{H} \mathrm{O} \mathrm{m}^{-2} \mathrm{~s}^{-1}$, while under stress conditions $T_{E}$ ranged from 0.33 to $2.64 \mu \mathrm{mol} \mathrm{H}_{2} \mathrm{O} \mathrm{m}^{-2} \mathrm{~s}^{-1}$ with an average of $1.23 \mu \mathrm{mol} \mathrm{H}_{2} \mathrm{O} \mathrm{m}^{-2} \mathrm{~s}^{-1}$. Regarding mean values, two sets of triplet genotypes (G11, G16, G18 and G8, G11, G17) were identified as the best genotypes under control and salinity stress conditions, respectively (Table 2).

\section{Root and shoot $\mathrm{Na}^{+}$and $\mathrm{K}^{+}$concentrations}

Root $\mathrm{Na}^{+}$and $\mathrm{K}^{+}$concentrations ( $\mathrm{RN}$ and RK), shoot $\mathrm{Na}^{+}$and $\mathrm{K}^{+}$concentrations (SN and SK), root and shoot $\mathrm{K}^{+} / \mathrm{Na}^{+}$ratios (RKN and SKN), root-to-shoot $\mathrm{Na}^{+}$translocation (RTSN), and root-to-shoot $\mathrm{K}^{+}$translocation (RTSK) changed significantly under salinity stress. Significant differences were also observed among the tested bread wheat genotypes in the parameters SN, SKN, RTSN, and RTSK, but the interaction effect was not significant for all parameters (Table 1). The mean values for SK, RKN, SKN, RTSN, and RTSK decreased under stress conditions by $23.34 \%, 94.87 \%, 43.15 \%, 83.84 \%$, and $31.14 \%$, respectively, relative to control conditions. In contrast, salinity stress increased ionic concentration-based parameters across all genotypes, with the means of RN, SN and RK increasing by $2431.21 \%, 50.74 \%$, and $29.38 \%$, respectively, compared to control (Table 3 ). 
Table 3

Mean values of ion content-related traits in the 20 bread wheat genotypes under control and salinity stress conditions

\begin{tabular}{|c|c|c|c|c|c|c|c|c|c|c|c|c|c|c|c|c|}
\hline \multirow[t]{2}{*}{ Genotype code } & \multicolumn{2}{|l|}{ RN } & \multicolumn{2}{|l|}{ RK } & \multicolumn{2}{|l|}{ SN } & \multicolumn{2}{|l|}{ SK } & \multicolumn{2}{|l|}{ RKN } & \multicolumn{2}{|l|}{ SKN } & \multicolumn{2}{|l|}{ RTSN } & \multicolumn{2}{|l|}{ RTSK } \\
\hline & ${ }^{+} \mathrm{C}$ & $S$ & C & $S$ & C & $S$ & C & $S$ & C & $S$ & C & $S$ & C & $S$ & C & $S$ \\
\hline G1 & 0.77 & 33.25 & 2.48 & 4.36 & 6.03 & 11.32 & 3.00 & 2.76 & 3.10 & 0.13 & 0.68 & 0.27 & 7.92 & 0.35 & 1.93 & 0.95 \\
\hline $\mathrm{G} 2$ & 0.85 & 14.82 & 3.15 & 1.23 & 4.06 & 5.49 & 4.44 & 3.26 & 5.90 & 0.08 & 1.18 & 0.61 & 7.23 & 0.52 & 1.43 & 4.16 \\
\hline G3 & 1.02 & 28.65 & 3.17 & 4.10 & 3.56 & 6.41 & 4.04 & 3.22 & 3.14 & 0.14 & 1.14 & 0.50 & 3.61 & 0.22 & 1.44 & 0.80 \\
\hline G4 & 0.78 & 31.52 & 1.48 & 4.01 & 7.46 & 4.95 & 2.87 & 1.71 & 1.83 & 0.13 & 0.42 & 0.35 & 10.60 & 0.17 & 3.24 & 0.43 \\
\hline G5 & 0.75 & 29.69 & 2.23 & 7.13 & 5.19 & 4.03 & 4.29 & 3.51 & 3.00 & 0.25 & 1.06 & 1.10 & 6.89 & 0.15 & 1.86 & 0.59 \\
\hline G6 & 0.78 & 34.78 & 2.63 & 3.94 & 5.29 & 7.04 & 4.43 & 2.58 & 3.13 & 0.12 & 0.98 & 0.41 & 6.71 & 0.22 & 3.08 & 0.65 \\
\hline G7 & 0.65 & 24.81 & 2.04 & 4.46 & 3.60 & 5.58 & 3.73 & 2.80 & 2.73 & 0.20 & 1.04 & 0.49 & 5.96 & 0.30 & 8.10 & 0.71 \\
\hline G8 & 0.85 & 25.39 & 2.40 & 4.11 & 7.30 & 15.52 & 4.02 & 3.60 & 2.78 & 0.12 & 0.76 & 0.29 & 8.44 & 1.15 & 1.73 & 9.92 \\
\hline G9 & 0.99 & 19.18 & 3.51 & 4.08 & 5.93 & 6.92 & 5.47 & 3.05 & 3.63 & 0.27 & 1.19 & 0.48 & 6.18 & 0.41 & 1.62 & 0.85 \\
\hline G10 & 1.02 & 28.47 & 2.05 & 3.96 & 5.13 & 9.30 & 3.56 & 3.14 & 2.08 & 0.17 & 0.79 & 0.37 & 5.90 & 0.33 & 6.87 & 0.88 \\
\hline G11 & 1.59 & 33.59 & 3.97 & 3.54 & 5.49 & 4.90 & 4.68 & 2.83 & 2.34 & 0.11 & 1.05 & 0.58 & 4.44 & 0.20 & 2.43 & 1.02 \\
\hline G12 & 0.82 & 17.01 & 1.61 & 1.68 & 3.66 & 9.03 & 5.30 & 4.31 & 1.91 & 0.09 & 1.59 & 0.54 & 4.32 & 0.84 & 3.79 & 4.41 \\
\hline G13 & 1.22 & 27.49 & 2.88 & 3.45 & 5.61 & 5.85 & 4.31 & 3.41 & 2.11 & 0.12 & 0.98 & 0.77 & 6.99 & 0.20 & 2.23 & 1.03 \\
\hline G14 & 1.39 & 19.33 & 3.15 & 1.96 & 3.69 & 8.58 & 4.83 & 2.88 & 1.81 & 0.09 & 1.29 & 0.40 & 3.67 & 0.42 & 8.21 & 5.76 \\
\hline G15 & 1.12 & 26.95 & 2.44 & 1.92 & 3.37 & 3.29 & 3.26 & 2.35 & 2.04 & 0.08 & 1.16 & 0.83 & 4.07 & 0.19 & 1.74 & 1.31 \\
\hline G16 & 1.09 & 21.37 & 2.21 & 2.32 & 7.20 & 3.29 & 4.21 & 3.14 & 2.15 & 0.10 & 0.71 & 1.19 & 7.20 & 0.18 & 1.86 & 1.80 \\
\hline G17 & 1.70 & 32.83 & 4.26 & 2.86 & 3.65 & 10.19 & 2.71 & 3.07 & 2.35 & 0.10 & 0.73 & 0.39 & 2.93 & 0.39 & 1.22 & 1.08 \\
\hline G18 & 1.36 & 44.77 & 3.07 & 5.22 & 5.34 & 14.09 & 2.49 & 2.47 & 2.14 & 0.13 & 0.69 & 0.17 & 3.68 & 0.32 & 1.14 & 0.59 \\
\hline G19 & 1.49 & 33.04 & 3.80 & 4.29 & 6.33 & 11.29 & 3.77 & 3.12 & 2.59 & 0.13 & 0.64 & 0.29 & 4.45 & 0.40 & 0.98 & 0.75 \\
\hline G20 & 1.73 & 29.02 & 4.47 & 5.14 & 2.92 & 4.90 & 2.79 & 2.71 & 2.65 & 0.18 & 0.94 & 0.78 & 1.72 & 0.17 & 0.62 & 0.55 \\
\hline Mean & 1.10 & 27.80 & 2.85 & 3.69 & 5.04 & 7.60 & 3.91 & 3.00 & 2.67 & 0.14 & 0.95 & 0.54 & 5.65 & 0.91 & 2.78 & 1.91 \\
\hline Std. & 0.06 & 1.65 & 0.21 & 0.27 & 0.31 & 0.57 & 0.21 & 0.13 & 0.23 & 0.01 & 0.06 & 0.04 & 0.48 & 0.55 & 0.54 & 0.52 \\
\hline${ }^{\ddagger} \mathrm{RC}(\%)$ & \multicolumn{2}{|c|}{-2431.21} & \multicolumn{2}{|l|}{-29.38} & \multicolumn{2}{|l|}{-50.74} & \multicolumn{2}{|l|}{23.34} & \multicolumn{2}{|l|}{94.87} & \multicolumn{2}{|l|}{43.15} & \multicolumn{2}{|l|}{83.84} & \multicolumn{2}{|l|}{31.14} \\
\hline \multicolumn{17}{|c|}{$\begin{array}{l}R N \text { root } \mathrm{Na}^{+} \text {content }\left(\mathrm{mmol} \mathrm{g}{ }^{-1} \mathrm{DW}\right), R K \text { root } \mathrm{K}^{+} \text {content }\left(\mathrm{mmol} \mathrm{g}{ }^{-1} \mathrm{DW}\right), S N \text { shoot } \mathrm{Na}^{+} \text {content }\left(\mathrm{mmol} \mathrm{g}^{-1} \mathrm{DW}\right), S K \text { shoot } \mathrm{K}^{+} \text {content }(\mathrm{mm} \\
R K N \text { root } \mathrm{K}^{+} / \mathrm{Na}^{+} \text {ratio, } S K N \text { shoot } \mathrm{K}^{+} / \mathrm{Na}^{+} \text {ratio, } R T S N \text { root-to-shoot } \mathrm{Na}^{+} \text {translocation, } R T K N \text { root-to-shoot } \mathrm{K}^{+} \text {translocation } \\
+C \text { control condition, } S \text { salinity stress }\end{array}$} \\
\hline
\end{tabular}

RN ranged from 0.65 to 1.73 (average $1.10 \mathrm{mmol} \mathrm{g}^{-1} \mathrm{DW}$ ) under control conditions and from 14.82 to $44.77 \mathrm{mmol} \mathrm{g}^{-1} \mathrm{DW}$ (average $27.80 \mathrm{mmol} \mathrm{g}^{-1} \mathrm{DW}$ ) under salinity stress. Under control conditions, the control varieties G1, G5, and G7 had the lowest RN content. Under salinity stress, the control varieties G2, G9, and G12 had the lowest RN content (Table 3). RK contents varied between 1.48 and $4.47 \mathrm{mmol} \mathrm{g}^{-1} \mathrm{DW}$ (average 2.85) and between 1.23 and 7.13 mmol g-1 DW (average 3.69) under control and stress conditions, respectively. Under control conditions, G11, G17, and G20 showed the highest K content in their root, while under salinity stress the highest $\mathrm{K}$ content was observed in genotypes G5, G18, and G20 (Table 3). SN content varied between 2.92 and $7.46 \mathrm{mmol} \mathrm{g}^{-1} \mathrm{DW}$ (average $5.04 \mathrm{mmol} \mathrm{g}^{-1} \mathrm{DW}$ ) in the control and from 3.22 to $15.52 \mathrm{mmol} \mathrm{g}^{-1} \mathrm{DW}$ (average $7.60 \mathrm{mmol} \mathrm{g} \mathrm{mW}^{-1} \mathrm{DW}$ ) under salinity stress. Under control conditions, G3, G15, and G20 had the lowest N content in the aboveground tissues, whereas G5, G15, and G16 had the lowest N content under stress condition (Table 3).

Values for SK content ranged from 2.71 to $5.47 \mathrm{mmol} \mathrm{g}^{-1}$ DW (average $3.91 \mathrm{mmol} \mathrm{g}^{-1}$ DW) and 1.71 to $3.60 \mathrm{mmol} \mathrm{g}^{-1} \mathrm{DW}$ (average $3 \mathrm{mmol} \mathrm{g}{ }^{-1}$ DW) under the control and stress conditions, respectively (Table 3). Under control conditions, RKN ranged from 1.81 to 5.90 (average 2.67) and two control varieties $\mathrm{G} 2$ and $\mathrm{G} 3$ along with $\mathrm{G} 8$ had the highest ratio compared to with other genotypes. Under stress conditions, this parameter varied between 0.08 and 0.27 (average 0.14 ) and the highest ratios were observed by genotypes G5, G7, and G9 (Table 3). Unlike RKN, the SKN showed a high range of variability among the investigated bread wheat genotypes. This parameter ranged from 0.64 to 1.79 (average 0.95 ) under control conditions and from 
0.27 to 1.19 (average 0.54) under stress conditions. The highest values under the control/stress conditions were estimated for G9/G5, G12/G15, and G14/G16. RTSN showed a significant change due to salinity stress and its mean decreased by $83.84 \%$ across tested genotypes when compared with control conditions. This parameter ranged from 1.72 to 10.60 and from 0.17 to 1.15 under control and stress conditions, respectively. Under control conditions, genotypes G14, G17, and G20 in the control and G4, G5, and G20 under salinity stress showed the greatest ability in maintaining Na ${ }^{+}$ions in their roots (Table 3). Furthermore, RTSK varied between 0.62 and 8.21 (average 2.78) in control conditions and between 0.55 and 5.76 (average 1.91 ) under salinity stress. Due to the effect of salinity stress on this parameter, RTSK decreased by $31.14 \%$ across the 20 investigated genotypes. Based on genotypic means, G7, G10, and G14 under control conditions and G8 and G14 and the control variety G2 under stress conditions showed the best ability in transfer of $\mathrm{K}^{+}$ions from root to shoot and mitigating salinity stress effects (Table 3 ).

\section{Grain yield}

The AMMI analysis of variance indicated that main effects due to environment (E), genotype (G), and genotype $\times$ environment interaction (GEI) were significant (Table 4). The E, G, and GEl accounted for $40.57 \%, 26.64 \%$, and $16.95 \%$ of the total variation. This analysis further divided the interaction's sum of squares into two interaction principal components (IPCA1 and IPCA2, respectively) and residual term. Both IPCAs were significant and explained $70.05 \%$ and $28.20 \%$ of the total variation due to the GEl, respectively. The mean grain yield of 20 investigated genotypes across four test environments are presented in Table 5. The mean yield varied between 3.96 tonnes $\mathrm{h}^{-1}$ at Yazd to 5.73 tonnes $\mathrm{h}^{-1}$ at Birjand. The highest grain yield was recorded for genotype G4, whereas genotype G16 had the lowest yield among all genotypes. However, there was crossover ranking across the tested locations. The highest-yield genotypes in Yazd, Kerman, Esfahan, and Birjand were G7, G5, G4, and G20, respectively, while genotypes G16, G19, G20, and G16, respectively, had the lowest yield at these locations. Means comparison revealed that genotype G4 followed by G9, G7, and G5 had the highest yield performance across four locations when compared with other genotypes (Table 5).

Table 4

$\mathrm{AMMI}$ analysis of variance for grain yield of the 20 investigated bread wheat genotypes

\begin{tabular}{|c|c|c|c|c|c|}
\hline Source of variation & $d f$ & Ms & F-value & $\%(G+E+G E)$ & $\%$ GE \\
\hline Treatments & 79 & 2.9 & $10.61^{\star \star}$ & & \\
\hline Genotype (G) & 19 & 3.82 & $13.97^{\star \star}$ & 26.64 & \\
\hline Environment (E) & 3 & 36.85 & $228.58^{\star \star}$ & 40.57 & \\
\hline Block & 8 & 0.16 & 0.59 & & \\
\hline $\mathrm{G} \times \mathrm{E}$ Interaction & 57 & 0.81 & $2.96^{\star *}$ & 16.95 & \\
\hline IPCA1 & 21 & 1.54 & $5.62^{\star \star}$ & 11.87 & 70.05 \\
\hline IPCA2 & 19 & 0.48 & $1.75^{\star}$ & 3.35 & 28.20 \\
\hline Residuals & 17 & 0.38 & 1.03 & 2.37 & \\
\hline Error & 152 & 0.27 & & 15.06 & \\
\hline \multicolumn{6}{|l|}{$\star, p<0.05 ; * *, p<0.01}$. \\
\hline
\end{tabular}


Table 5

Mean grain yield ( $t$ ha- 1 ) of the 20 investigated bread wheat genotypes across four saline regions

\begin{tabular}{|c|c|c|c|c|c|c|}
\hline Genotype code & Yazd & Kerman & Esfahan & Birjand & †Overall mean & ${ }^{\ddagger}$ ASR \\
\hline G1 & $4.23(6)$ & $4.33(14)$ & $5.40(12)$ & $5.08(17)$ & $4.76^{\mathrm{BCDEF}}$ & $12.25(13)$ \\
\hline $\mathrm{G} 2$ & $3.59(15)$ & $4.72(11)$ & $5.36(13)$ & 4.69 (19) & $4.59 \mathrm{DEF}$ & $14.50(17)$ \\
\hline G3 & $4.17(9)$ & $4.91(9)$ & $5.43(11)$ & $5.75(11)$ & $5.06^{A B C D}$ & $10.00(11)$ \\
\hline G4 & $4.20(8)$ & $5.72(2)$ & $5.84(1)$ & $5.83(9)$ & $5.40^{\mathrm{A}}$ & $5.00(1)$ \\
\hline G5 & $4.16(10)$ & $6.21(1)$ & $5.15(15)$ & $5.74(13)$ & $5.31^{A B C}$ & $9.75(10)$ \\
\hline G6 & $3.87(13)$ & $4.95(6)$ & $5.69(4)$ & $6.19(5)$ & $5.18^{A B C D}$ & $7.00(6)$ \\
\hline G7 & $4.87(1)$ & $4.71(12)$ & $5.49(9)$ & $6.40(3)$ & $5.37^{A B}$ & $6.25(5)$ \\
\hline G8 & $4.60(4)$ & $5.11(3)$ & $5.64(7)$ & $5.87(8)$ & $5.31^{A B C}$ & $5.50(2)$ \\
\hline G9 & $4.67(3)$ & $4.94(8)$ & $5.48(10)$ & $6.46(2)$ & $5.39^{A}$ & $5.75(4)$ \\
\hline G10 & $4.85(2)$ & $4.91(9)$ & $5.60(8)$ & $5.75(11)$ & $5.28 \mathrm{ABC}$ & $7.50(7)$ \\
\hline G11 & $4.43(5)$ & $4.95(6)$ & $5.67(5)$ & $5.67(15)$ & $5.18 \mathrm{ABCD}$ & $7.75(8)$ \\
\hline G12 & $4.22(7)$ & $4.97(5)$ & $5.74(3)$ & $5.88(7)$ & $5.20 \mathrm{ABCD}$ & $5.50(2)$ \\
\hline G13 & $3.99(11)$ & $4.98(4)$ & $5.76(2)$ & $5.74(14)$ & $5.12^{A B C D}$ & 7.75 (8) \\
\hline G14 & $3.74(14)$ & $4.47(13)$ & $5.67(5)$ & $5.54(16)$ & $4.86^{\mathrm{ABCDE}}$ & $12.00(12)$ \\
\hline G15 & $3.29(18)$ & $4.09(15)$ & $5.16(14)$ & $6.34(4)$ & $4.72^{\mathrm{CDEF}}$ & $12.75(14)$ \\
\hline G16 & $2.54(20)$ & 3.22 (17) & $4.05(18)$ & $4.63(20)$ & $3.61^{\mathrm{H}}$ & $18.75(20)$ \\
\hline G17 & $3.10(19)$ & $3.48(16)$ & $4.20(17)$ & $5.96(6)$ & $4.19 \mathrm{FG}$ & $14.50(17)$ \\
\hline G18 & $3.89(12)$ & $2.75(19)$ & $4.80(16)$ & $5.81(10)$ & $4.31 \mathrm{EF}$ & $14.25(16)$ \\
\hline G19 & 3.38 (17) & $2.63(20)$ & $3.94(19)$ & 4.71 (18) & $3.67^{\mathrm{GH}}$ & 18.50 (19) \\
\hline G20 & $3.58(16)$ & $2.85(18)$ & $3.91(20)$ & $6.63(1)$ & $4.24^{\mathrm{F}}$ & $13.75(15)$ \\
\hline $\begin{array}{l}\text { Numbers in pare } \\
\text { † Different letter } \\
\text { ‡ Average of sun } \\
\text { See Table S1 for }\end{array}$ & $\begin{array}{l}\text { theses indi } \\
\text { in each row } \\
\text { of ranks fo } \\
\text { definition of }\end{array}$ & $\begin{array}{l}\text { ate the rank } \\
\text { indicate sic } \\
\text { each geno } \\
\text { genotypes. }\end{array}$ & $\begin{array}{l}\text { ng pattern } \\
\text { ificant diff } \\
\text { pe across } f\end{array}$ & $\begin{array}{l}\text { ross all ge } \\
\text { ences at } 0 . \\
\text { ur test loca }\end{array}$ & $\begin{array}{l}\text { otypes. } \\
1 \text { probability leve } \\
\text { ons. }\end{array}$ & \\
\hline
\end{tabular}

\section{Association among seedling-based physiological traits and grain yield under stress condition}

Principal component analysis (PCA) was performed to dissect the total variance in the main features and to assess the relationships among the investigated genotypes and measured traits under salinity stress conditions. The results revealed that the two first principal components (PCs) justified $46.64 \%$ of the total variation in data with eigenvalues of 4.37 and 3.56 , respectively. The first PC accounted for $25.70 \%$ of the variation and was strongly correlated with $P_{N}, G_{S}, T_{E}, \mathrm{SN}, \mathrm{RN}, \mathrm{RTSN}$, and RTSK but was negatively correlated with SDW, RN, RK, RKN, and RSN. The second PC accounted for $20.93 \%$ of the total variation and was positively correlated with SPAD index, RWC, RDW, SDW, RN, MSI, and SKN but was negatively associated with RK, SN, SK, RKN, RTSN, RTSK, and grain yield (factor loadings not shown).

A biplot analysis was also used to show which genotype performed best for certain trait(s) and to identify the more salinity-tolerant genotypes based on the multiple measured traits. As there is not a clear pattern of association between factor loadings and multiple traits, we selected tolerant genotypes for specific trait(s). Accordingly, the genotype numbers G5, G6, G7, and G10 along with two control varieties G1 and G3 were associated with RK, RKN, and grain yield. The genotypes G8, G11, and G12 were associated with SN, SK, RTSK, and RTSN traits. Among the measured traits, $P_{N}, G_{S}$, and $T_{E}$ discriminated the control variety G2 and G14 from other genotypes. The genotypes G15, G16, and G17 showed a strong association with RWC, MSI, SPAD index, and RDW. Other genotypes (G4, G13, G18, G19, and G20) were associated with RN, SDW, and SKN (Fig. 1). 
Figure 1 also depicts a relationship among the measured physiological traits at the seedling stage and grain yield. A small angle between two trait vectors shows a strong positive correlation and a larger angle shows a weaker correlation. Moreover, the $90^{\circ}$ and $180^{\circ}$ angles would result if there were no correlation and a negative correlation between the traits, respectively. Accordingly, grain yield showed a positive and strong correlation with RKN and RK. Furthermore, grain yield had a positive but a weak correlation with SK, SN, and RTSN. This result was also confirmed by linear regressions among the ranking pattern for grain yields with RN, RK, SN, SK, RKN, and SKN (Fig. 2). The correlation among $P_{N}, G_{S}$, and $T_{E}$ traits was strong and positive and had a positive correlation with RWC, MSI, RDW, and SPAD index. RDW and SDW were positively correlated with RN, SKN, SPAD index, MSI, and RWC. The relatedion translocation parameters (RTSN and RTSK) were positively correlated with SN and SK but had a negative correlation with RN and RK. SDW positively correlated with SK and SKN but was negatively associated with SN.

\section{Identification of superior salinity-tolerant genotypes}

Due to the difficulty in identifying superior tolerant genotypes based on a single measured trait, we used the average of sum ranks (ASR) of all traits. In this way, the investigated genotypes received a rank from 1 and 20 for each trait such that the best mean of each trait received the lowest rank; thus the genotypes with the lowest ASR values were identified as the superior genotypes. Genotypes G5, G13, G15, G16, G17, and G20 had the lowest ASRs and were considered the best genotypes (Supplementary Table S2). On the other hand, the ranking pattern of genotypes based on grain yield recognized G4, G5, G7, G8, and G9 as high-yield performance genotypes relative to other genotypes. Indeed, these results indicate that there is a strict correlation between tolerance pattern existence in the seedling stage and whole plant (Fig. 3). Thus, an increase in ASR value at the seedling stage correlated with reduced yield performance at the field stage. Based on these results, G5 may be a candidate as a superior salinity-tolerant genotype due to its high performance in the field and its response to a high level of salinity at the seedling stage.

\section{Discussion}

Crops commonly encounter environmental stresses. Among these, salinity is a major stress that suppresses plant growth and crop productivity globally (Long et al. 2020). The negative effects of salinity stress on plant growth, development, and ultimately yield performance may be attributed to the imbalance of various ions and ion toxicity, low osmotic potential of soil solution, reduction in carbon fixation, stomatal conductivity and photosynthesis rate, and nutritional imbalances (Sadak 2019). In the present study, 17 advanced genotypes of bread wheat along with three local check varieties were evaluated for their root and shoot biomass, root and shoot ion concentrations, and several physiological traits under two control and salinity stress treatments to reveal genotypes and tolerance mechanisms that may be reliable for the selection of ideal genotypes at the seedling stage. Furthermore, the yield performance of the investigated bread wheat genotypes was compared with each other and the control varieties across four salinity regions. Our findings indicated that the impact of salinity stress on the response of plant seedlings and whole plants was significantly dependent on genotype, as significant differences were observed for SDW, RWC, $P_{N}, G_{S}, T_{E}, \mathrm{SN}, \mathrm{SKN}, \mathrm{RTSN}$, and RTSK (Table 1). Salinity stress significantly reduced the SKN (94.87\%), RTSN (83.84\%), SDW (49.98\%), $G_{S}(44.63 \%), \operatorname{SKN}(43.15 \%), P_{N}(32.15 \%), \operatorname{RTSK}(31.14 \%), \operatorname{RDW}(24.44 \%)$, SK $(23.34 \%)$, and $T_{E}(14.25 \%)$ when compared with control conditions (Tables 2 and 3). In contrast, salinity stress significantly increased RN (2431.21\%), SN (50.74\%), and RK (29.38\%).

Under salinity stress conditions, shoot growth is more sensitive than root growth. According to Munns and Tester's (2008) theory, a reduction in leaf area development rather than root growth may decrease water use by the plant and thus allow it to conserve soil moisture and decrease soil salt concentration. Thus, a reduction in shoot growth due to salinity is commonly expressed by a reduced leaf area (Lauchli and Epstein 1990). Our results showed that the percentage of reduction of SDW is more than RDW under salinity stress conditions compared to control conditions (Table 2). Generally, a reduction in root and shoot biomass can be supported by the findings of Islam et al. (2015), who indicated that reduction in these growth parameters was associated with a decrease in photosynthesis due to reduced leaf area that results in reduced plant biomass (Jallel et al. 2007). In the present study, we found that genotypes G15 and G17 had the highest root and shoot dry biomasses than the other genotypes (Table 2). Furthermore, these genotypes showed an increasing pattern in root biomass due to salinity stress compared to control conditions (45.37 and $60.81 \%$, respectively). This increasing trend under salinity conditions is a possible stress-avoidance mechanism. In addition to root and shoot dry biomass, salinity stress had an adverse effect on ion concentrations and many physiological traits; the rate of reduction or increase in the various measured traits in different crop plants was significantly associated with increase in salt concentration (Sadak 2019; Ahmadi et al. 2018, Ebrahim et al. 2020; Ahmadi et al. 2020; Zeeshan et al. 2020).

One of the main consequences of salinity stress is loss of intracellular water content. The water status of plant cells is the key factor that affects plant growth and development (Islam et al. 2016). RWC is a physiological parameter that measures the water content of a leaf and the maximum amount that can take under full turgidity (Qin et al. 2010). Through RWC analysis, we observed that there were no significant differences between levels of salinity treatments, although salinity caused an approximate $4 \%$ reduction of RWC compared to control conditions (Table 2 ). This finding may be supported by the effect of higher osmolyte concentration, which may be reflected by the maintenance of higher RWC. However, this result is inconsistent with other reports, which have shown that salinity stress can decrease the water content level in plants (Suriya-Arunroj et al. 2004; Suarez and Medina 2008; Qin et al. 2010). MSI is another physiological parameter that is considered an indicator of stress tolerance and is widely used to measure potential salinity tolerance in different crops (Blum and Ebrecon 1981; Sairam and Sirvastava 2002; Senguttuvel et al. 2014; ElBasyoni et al. 2017; Ebrahim et al. 2020). Farooq and Azam (2006) also noted that MSI is more effective than grain-yield reduction in screening tolerant genotypes at the seedling stage. This parameter is often affected by lipid peroxidation caused by ROS under salinity stress conditions, which results in the production of malondialdehyde (MDA) (Ahmed et al. 2013). Furthermore, this is a quantitative trait, which through moderate heritability has a high genetic correlation with grain yield (Asif and Kamran 2011; Ali et al. 2014; Hemantaranjan 2014; Talukder et al. 2014). In the present study, MSI changed modestly when plants were exposed to salinity stresses relative to control conditions (Table 2). As a result, several genotypes showed the highest MSI parameters. G17 and G20, along with 
$\mathrm{G} 18, \mathrm{G} 19$, and the control salt-tolerant genotype $\mathrm{G} 1$ showed an increasing trend in response to salinity stress. Plants have evolved different protective mechanisms either to exclude salts from their cells or to tolerate its presence within the cells (Carillo et al. 2014). One of the main protective mechanisms is the ability to control the balance of $\mathrm{Na}^{+}$and $\mathrm{K}^{+}$accumulation in different plant tissues. Hence, the assessment of $\mathrm{Na}^{+}$and $\mathrm{K}^{+}$accumulation in root and shoot is essential to infer salt-tolerance mechanisms (Islam et al. 2915). Exclusion of $\mathrm{Na}^{+}$and maintaining a high $\mathrm{K}^{+}$concentration is required for maintaining a high $\mathrm{K}^{+} / \mathrm{Na}^{+}$ratio in plants. Hence, the $\mathrm{K}^{+} / \mathrm{Na}^{+}$ratio is considered one of the main physiological strategies adopted by plants to resist salt stress (Singh et al. 2019). Our results suggest that ion concentrations and high $\mathrm{K}^{+} / \mathrm{Na}^{+}$ratios may be useful selection indices for salt tolerance, consistent with the findings of Genc et al. (2010), Xu et al. (2012), Masoudi et al. (2015), and Ahmadi et al. (2020). We observed that genotypes G5 and G20 showed the lowest SN and highest RK, SK, RKN, and SKN. Finally, RTSN indicated that these genotypes can be selected as superior tolerant genotypes (Table 3).

In addition to the reduction in root and shoot biomass, a marked reduction in $G_{S} P_{N}, T_{E}$ and SPAD parameters due to salinity stress was recorded in the investigated wheat genotypes (Table 2). These negative effects are possibly due to either single or combined effects of increased ROS and inhibition of metabolic phenomena that can increase oxygen-induced cellular damage (Neill et al. 2002). The regulation of gas exchange between the inner air space of the leaf and the outer atmosphere is controlled by two small symmetric guard cells. $G_{S}$ is regulated primarily by stomatal density, the aperture of the stomatal pore, and the water-transport capacity of the guard cells on the leaf surface (Zhu et al. 2018). This parameter estimates the rate of $\mathrm{CO}_{2}$, and transpiration using stomata is determined due to the degree of physical resistance to gas movement between the leaf interior and ambient air (Pietragalla and Pask 2012; Pour-Aboughadareh et al. 2017). In our study, salinity stress reduced $G_{S}$ by $44.63 \%$ when averaged across all investigated genotypes (Table 2). This result is consistent with a study conducted by Mahlooji et al. (2018) where a reduction in $G_{S}$ occurred due to salinity stress. In this case, genotypes $\mathrm{G} 8, \mathrm{G} 11, \mathrm{G} 14, \mathrm{G} 16$, and $\mathrm{G} 17$ had the highest $G_{S}$ values (Table 2). G8, G14, and $\mathrm{G} 16$ had a relatively smaller reduction or even an increasing trend in stomatal conductivity than the other genotypes and the control varieties (Table 2).

Photosynthesis is often reduced due to salinity stress regardless of the type of salts encountered (Misra et al. 1997). In photosynthetic tissues, Na+ accumulation affects photosynthetic components such as chlorophylls, carotenoids, and enzymes. The reduction in photosynthetic rate in salt-sensitive plants can also increase the production of ROSs (Davenport et al. 2005). In this study, when compared with control conditions, $P_{N}$ values of salt-treated seedling plants were relatively low. Salinity reduced $P_{N}$ values by $32.15 \%$ when averaged across all the tested genotypes (Table 2 ). Under salinity stress, the trend of photosynthesis rate was $\mathrm{G} 10>\mathrm{G} 9>\mathrm{G} 16>\mathrm{G} 8>\mathrm{G} 14>$ other genotypes and the control varieties (Table 2). According to our results, the transpiration rate was also affected by salinity stress; the average of this parameter across all genotypes was reduced by $14.25 \%$ compared with the control. Genotypes G14, G8, G11, G17, and G16 had the highest values (Table 2). These results revealed that there is a strong association among $G s, P_{N}$, and $T_{E}$, as among the selected genotypes $\mathrm{G} 8, \mathrm{G} 14$, and $\mathrm{G} 16$ had the highest values of these parameters. This result is in contrast to a previous study, where stomatal closure was shown to be as effective of a mechanism for maintaining water content under salinity stress and limiting uptake of harmful salt ions (Hasegawa et al. 2000). Thus, there is a possibility that some of the genotypes were resistant to salinity stress due to increasing stomatal conductivity and maintenance of photosynthesis capacity. In some studies, use of the ASR for multiple traits had been recommended to identify superior genotypes (Pour-Aboughadareh et al. 2019; Pour-Aboughadareh et al. 2020). In this way, the best genotypes received the minimum rank for each trait or parameter. Thus, genotypes with the lowest ASR values were identified as superior genotypes. Our results showed that genotypes G5, G13, G15, G16, G17, and G20 had the lowest ASRs and were therefore identified as the best genotypes compared with the control varieties and other genotypes

(Supplementary Table S2)

In the present study, results of AMMI analysis of variance revealed significant differences among the investigated bread wheat genotypes and test locations (Table 4). These findings indicate that there is a high level of variation for grain-yield performance across all investigated genotypes in response to salinity stress. From the means comparison, the highest mean grain yields were recorded for genotypes G4, G5, G7, and G9 (Table 5). The PCA-based biplot revealed a considerable association between grain yield and some of the physiological traits at the seedling stage. Grain yield positively and significantly correlated with RK and RKN (Fig. 1). Indeed, this result supports the fact that selection in the early stage may lead to achieving tolerant and high-yield genotypes, and furthermore these parameters can be used as useful physiological tools to screen salt-tolerant genotypes at the early growth stage. Our results also indicated an association between the ranking patterns for grain yield and ASR-based all measured traits (Fig. 3). Considering our results, genotype G5 showed an acceptable ASR value and high-yield performance. The pedigree of this promising genotype is

"Arg/5/Seri*3//RL6010/4*YR/3/Pastor/4/Bav92" in which cultivar "Arg" contributed as one of the Iranian landraces that is considered as the best salinitytolerant parent in crossing programs. Cultivar "Arg" was formerly obtained from a hybridization between an Iranian landrace and international parent (cv. Inia from CIMMYT). This cultivar, with a productivity of 5.5 tonnes per hectare, is still favored by some farmers as it can tolerate a high level of water and soil salinity (10 and $12 \mathrm{dS} \mathrm{m}^{-1}$, respectively) in the saline regions of Iran. Due to these features, we surmise genotype G5 is expected to perform successfully in target regions and to be adopted by farmers as its progenitor. Furthermore, the presence of "Pastor" as one of the main parents in this pedigree may have contributed to improved field resistance to stripe rust. We can conclude that genotype G5 can be recommended as a superior bread wheat genotype for cultivation in saline environments.

\section{Conclusion}

Our results revealed genetic variation among breeding bread wheat genotypes for salinity tolerance in terms of several physiological traits at the early growth and grain yield. As a result, our findings indicate there is a positive correlation between salinity tolerance at the seedling stage and grain-yield performance at the adult phase. This result may allow for a reconsideration of the associations between tolerance at the seedling and adult phases of growth and of the complex connections among different physiological and photosynthesis parameters in resistance to salinity stress. The increased 
tolerance of genotype G5 was due to the lower concentration of $\mathrm{Na}^{+}$and higher RKN and SKN. In addition, this genotype had high-yield performance in different saline regions of Iran. Hence, further study is needed to explore the underlying physiological and molecular mechanisms and to investigate its yield stability and adaptation in severe saline environments.

\section{Declarations}

\section{Compliance with ethical standards}

Conflict of Interest Authors declared no conflict of interest.

\section{Author contribution statement}

AP conceived and designed the experiment. AA (the forth author) provided the seeds of breeding genotypes. The experiment was performed by AP and AA (the sixth author). AP, MM, SS and AA (the sixth author) collected the experimental data. AP performed the analysis and wrote the manuscript. MM and SS provided comments and edits. All authors read and approved the final manuscript.

\section{Acknowledgements}

The authors acknowledge the lab facilities support (No. 2-03-03-236-980895) from the Seed and Plant Improvement Institute (SPII), Agricultural Research, Education and Extension Organization (AREEO), Iran. The authors thank the reviewers and the editor of Acta Physiologiae Plantarum for providing helpful comments and corrections on earlier drafts of this manuscript. Also, the first author is grateful to Dr. Peter Poczai, from the Botany Unit, Finnish Museum of Natural History, University of Helsinki, for his fruitful comments and improve the langue of the manuscript.

\section{References}

1. Acosta-Motos JR, Ortuno MF, Bernal-Vicente A, Diaz-Vivancos P, Sanchez-Blanco MJ, Hernandez JA (2017) Plant responses to salt stress: adaptive mechanisms. Agronomy 7:18. https://doi.org/10.3390/agronomy7010018

2. Afzal I, Rauf S, Basra SMA, Murtaza G (2008) Halopriming improves vigor, metabolism of reserves and ionic contents in wheat seedlings under salt stress. Plant Soil Environ 54:382-388. https://doi.org/10.17221/408-PSE

3. Ahmadi J, Pour-Aboughadareh A, Fabriki Ourang S, Khalili P, Poczai P (2020) Unraveling salinity stress responses in ancestral and neglected wheat species at early growth stage: A baseline for utilization in future wheat improvement programs. Physiol Mol Biol Plants 26:537-549. https://doi.org/10.1007/s12298-020-00768-4

4. Ahmadi J, Pour-Aboughadareh A, Fabriki-Ourang S, Mehrabi AA, Siddique KHM (2018) Screening wild progenitors of wheat for salinity stress at early stages of plant growth: insight into potential sources of variability for salinity adaptation in wheat. Crop Pasture Sci 69:649-658. https://doi.org/10.1071/CP17418

5. Ahmed IM, Cao F, Zhang M, Chen X, Zhang G, Wu F (2013) Difference in yield and physiological features in response to drought and salinity combined stress during anthesis in Tibetan wild and cultivated barleys. Plos One 8:e77869. https://doi.org/10.1371/journal.pone.0077869

6. Akbarimoghaddam H, Galavi M, Ghanbari A, Panjehkeh N (2011) Salinity effects on seed germination and seedling growth of bread wheat cultivars. Trakia J Sci 9:43-50

7. Ali MA, Niaz S, Abbas A, Sabir W, Jabran K (2009) Genetic diversity and assessment of drought tolerant sorghum landraces based on morphphysiological traits at different growth stages. Plant Omics 2:214-227

8. Anil VS, Krishnamurthy H, Mathew MK (2007) Limiting cytosolic $\mathrm{Na}^{+}$confers salt tolerance to rice cells in culture: a two-photon microscopy study of SBFI loaded cells. Physiol Plant 129:607-621. https://doi.org/10.1111/j.1399-3054.2006.00854.x

9. Arfan M, Athar HR, Ashraf M (2007) Does exogenous application of salicylic acid through the rooting medium modulate growth and photosynthetic capacity in difgerently adapted spring wheat cultivated under salt stress? J Plant Physiol 6:685-694. https://doi.org/10.1016/j.jplph.2006.05.010

10. Arzani A, Ashraf A (2016) Smart engineering of genetic resources for enhanced salinity tolerance in crop plants. Crit Rev Plant Sci 35:146-189. https://doi.org/10.1080/07352689.2016.1245056

11. Ashraf M, Akram NA (2009) Improving salinity tolerance of plants through conventional breeding and genetic engineering: an analytical comparison. Biotechnol Adv 27:74452. https://doi.org/10.1016/j.biotechadv.2009.05.026

12. Asif M, Kamran A (2011) Plant breeding for water-limited environments. Crop Sci 51:2911-2912. https://doi.org/10.2135/cropsci2011.12.0004br

13. Athar HUR, Khan A, Ashraf M (2007) Exogenously applied ascorbic acid alleviates salt-induced oxidative stress in wheat. Environ Exp Bot 63:224231. https://doi.org/10.1016/j.envexpbot.2007.10.018

14. Blum A (2010) Plant breeding for water-limited environments. Springer, New York

15. Blum A, Ebrecon A (1981) Cell membrane stability as measure of drought and heat tolerance in wheat. Crop Sci 21:43-47. http://dx.doi.org/10.2135/cropsci1981.0011183X002100010013x

16. Carillo P, Grazia Annunziata M, Pontecorvo G, Fuggi A, Woodrow P (2011) Salinity Stress and Salt Tolerance. In: Shanker A (ed) Abiotic Stress in Plants - Mechanisms and Adaptations. IntechOpen, UK, pp 21-38 
17. Chen F, Dahal P, Bradford KJ (2001) Two tomato expansin genes show divergent expression and localization in embroys during seed development and germination. Plant Physiol 127:928-936. https://doi.org/10.1104/pp.010259

18. Dadshani S, Sharma RC, Baum M, Ogbonnaya FC, Leon J, Ballvora A (2019) Multidimensional evaluation of response to salt stress in wheat. Plos One 14:e0222659. https://doi.org/10.1371/journal.pone.0222659

19. Davenport R, James R, Zakrisson-Plogander A, Tester M, Munns R (2005) Control of sodium transport in durum wheat. Plant Physiol 137:807-818. https://doi.org/10.1104/pp.104.057307

20. Ebrahim F, Arzani A, Rahimmalek M, Sun D, Peng J (2019) Salinity tolerance of wild barley Hordeum vulgare ssp. spontaneum. Plant Breed 139:304316. https://doi.org/10.1111/pbr.12770

21. ElBasyoni I, Saadalla M, Baenziger S, Bockelman H, Morsy S (2017) Cell membrane stability and association mapping for drought and heat tolerance in a worldwide wheat collection. Sustainability 9:1606. https://doi.org/10.3390/su9091606

22. Farooq S, Azam F (2006) The use of cell membrane stability (CMS) technique to screen for salt tolerant wheat varieties. J Plant Physiol 163:629637. https://doi.org/10.1016/j.jplph.2005.06.006

23. Food and agriculture organization (2020) available at http://www.fao.org/worldfoodsituation/csdb/en/

24. Geilfus CM, Niehaus K, Godde V, Hasler M, Zorb C, Gorzolka K, Jezek M, Senbayram M, Ludwing-Muller J, Muhling KH (2015) Fast responses of metabolites in Vicia faba L. to moderate NaCl stress. Plant Physiol Biochem 92:19-29. https://doi.org/10.1016/j.plaphy.2015.04.008

25. Genc Y, Oldach K, Verbyla AP, Lott G, Hassan M, Tester M, Wallwork H, McDonald GK (2010) Sodium exclusion QTL associated with improved seedling growth in bread wheat under salinity stress. Theor Appl Genet 121:877-894. https://doi.org/10.1007/s00122-010-1357-y

26. GENSTAT [computer software] (2008) VSN International Ltd.

27. Ghiyasi M, Seyahjani AA, Tajbakhsh M, Amirnia R, Salehzadeh H (2008) Effect of osmopriming with polyethylene glycol (8000) on germination and seedling growth of wheat (Triticum aestivum L.) seeds under salt stress. Res J Biol Sci 3:1249-1251

28. Guo R, Yang Z, Li F, Yan C, Zhong X, Liu Q, Xia X, Li H, Zhao L (2015) Comparative metabolic responses and adaptive strategies of wheat (Triticum aestivum) to salt and alkali stress. BMC Plant Biol 15:170. https://doi.org/10.1186/s12870-015-0546-X

29. Hagemann M, Erdmann N (1997) Environmental stresses. In: Rai AK (ed) Cyanobacterial nitrogen metabolism and environmental biotechnology. Springer, Heidelberg, pp 156-221

30. Hasanuzzaman M, Nahar K, Rahman A, Anee TI, Alam MU, Bhuiyan TF, Oku H, Fujita M (2017) Approaches to enhance salt stress tolerance in wheat. In: Wanyera R (ed) Wheat improvement, management and utilization. InTech, London, pp 151-187. http://dx.doi.org/10.5772/67247

31. Hasegawa PM, Bressan RA, Zhu JK, Bohnert HJ (2000) Plant cellular and molecular responses to high salinity. Annu Rev Plant Physiol Plant Mol Biol 51:463-499. https://doi.org/10.1146/annurev.arplant.51.1.463

32. Hasegawa PM, Bressan RA, Zhu JK, Bohnert HJ (2000) Plant cellular and molecular responses to high salinity. Annu Rev Plant Physiol Plant Mol Biol 51:463-499

33. Hemantaranjan A (2014) Heat Stress Responses and Thermotolerance. Adv Plants Agric Res 1:1-10. https://doi.org/10.15406/apar.2014.01.00012

34. Hoagland DR, Arnon DI (1950) The water-culture method for growing plants without soil. California Agricultural Experiment Station, Circular No. 374. The College of Agriculture, University of California, Berkeley

35. Husain S, Munns R, Condon AG (2003) Effect of sodium exclusion trait on chlorophyll retention and growth of durum wheat in saline soil. Aust J Agr Res 54:589-597. https://doi.org/10.1071/AR03032

36. Isayenkov SV, Maathuis FJM (2019) Plant salinity stress: many unanswered questions remain. Front Plant Sci 10:80. https://doi.org/10.3389/fpls.2019.00080

37. Islam F, Yasmeen T, Ali S, Ali B, Farooq MA, Gill RA (2015) Priming-induced antioxidative responses in two wheat cultivars under saline stress. Acta Physiol Plant 37:153. https://doi.org/10.1007/s11738-015-1897-5

38. Islam F, Yasmeen T, Arif MS, Ali S, Ali B, Hameed S, Zhou W (2016) Plant growth promoting bacteria confer salt tolerance in Vigna radiate by upregulating antioxidant defense and biological soil fertility. Plant Growth Regul 80:23-36. https://doi.org/10.1007/s10725-015-0142-y

39. Kawasaki S, Borchert C, Deyholos M, Wang H, Brazille S, Kawai K, Galbraith D, Bohnert HJ (2001) Gene expression profiles during the initial phase of salt stress in rice. Plant Cell 13:889-905. https://doi.org/10.1105/tpc.13.4.889

40. Ketata HY, Yau SK, Nachit M (1989) Relative consistency performance across environments. In: International Symposium on Physiology and Breeding of Winter Cereals for stressed Mediterranean Environments, Montpellier, July 3-6, pp. 391-400

41. Lauchli A, Epstein E (1990) Plant response to salinity and sodic conditions. ASCE Man Rep Eng Pratt 71:113-137. https://doi.org/10.1061/9780784411698.ch06

42. Liu S, Constable G, Stiller W (2020) Using leaf sodium concentration for screening sodicity tolerance in cotton (Gossypium hirsutum L.). Field Crop Res 46:107678. https://doi.org/10.1016/j.fcr.2019.107678

43. Long M, Shou J, Wang J, Hu W, Hannan F, Mwamba TM, Farooq MA, Zhou W, Islam F (2020) Ursolic acid limits salt-induced oxidative damage by interfering with nitric oxide production and oxidative defense machinery in rice. Front Plant Sci 11:697. https://doi.org/10.3389/fpls.2020.00697

44. Maghsoudi K, Emam Y, Pessarakli M (2016) Effect of silicon on photosynthetic gas exchange, photosynthetic pigments, cell membrane stability and relative water content of different wheat cultivars under drought stress conditions. J Plant Nutr 39:1001-1015.

https://doi.org/10.1080/01904167.2015.1109108

Page $14 / 17$ 
45. Mahlooji M, Seyed Sharifi R, Razmjoo J, Sabzalian MR, Sedghi M (2018) Effect of salt stress on photosynthesis and physiological parameters of three contrasting barley genotypes. Photosynthetica 56:549-556. https://doi.org/10.1007/s11099-017-0699-y

46. Masoudi B, Mardi M, Majidi Hervan E, Bihamta MR, Naghavi MR, Nakhoda B, Amini A (2015) QTL mapping of salt tolerance traits with different effects at the seedling stage of bread wheat. Plant Mol Biol Rep 33:1790-1803. https://doi.org/10.1007/s11105-015-0874-x

47. Misra A, Sahu AN, Misra M, Singh P, Meera I, Das N, Kar M, Sahu P (1997) Sodium chloride induced changes in leaf growth, and pigment and protein contents in two rice cultivars. Biol Plant 39:257-262. http://dx.doi.org/10.1023/A:1000357323205

48. Munns R, Schachtman D, Condon A (1995) The Significance of a Two-Phase Growth Response to Salinity in Wheat and Barley. Funct Plant Biol 22:561-569. https://doi.org/10.1071/PP9950561

49. Munns R, Tester M (2008) Mechanisms of salinity tolerance. Annu Rev Plant Biol 59:651-681. https://doi.org/10.1146/annurev.arplant.59.032607.092911

50. Neill SJ, Desikan R, Clarke A, Hurst RD, Hancock JT (2002) Hydrogen peroxide and nitric oxide as signaling molecules in plants. J Exp Bot 53:12371247. https://doi.org/10.1093/jexbot/53.372.1237

51. Nevo E, Chen G (2010) Drought and salt tolerances in wild relatives for wheat and barley improvement. Plant Cell Environment 33:670-685. https://doi.org/10.1111/j.1365-3040.2009.02107.x

52. Oyiga BC, Sharma RC, Shen J, Baum M, Ogbonnaya FC, Leon J, Ballvora A (2016) Identification and Characterization of Salt Tolerance of Wheat Germplasm Using a Multivariable Screening Approach. J Agron Crop Sci 202:472-485. https://doi.org/10.1111/jac.12178

53. Panwar M, Tewari R, Gulati A, Nayyar H (2016) Indigenous salt-tolerant rhizobacterium Pantoea dispersa (PSB3) reduces sodium uptake and mitigates the effects of salt stress on growth and yield of chickpea. Acta Physiol Plant 38:278. https://doi.org/10.1007/s11738-016-2284-6

54. Pietragalla J, Pask AJD (2012) Physiological breeding II. In: Pietragalla H, Pask AJD, Mullan D, Reynold MP (eds) A field guide to wheat phenotyping. CIMMYT, Mexico, pp 15-17

55. Pour-Aboughadareh A, Ahmadi J, Mehrabi AA, Etminan A, Moghaddam M, Siddique KHM (2017) Physiological responses to drought stress in wild relatives of wheat: Implications for wheat improvement. Acta Physiol Plant 39:106. https://doi.org/10.1007/s11738-017-2403-z

56. Pour-Aboughadareh A, Etminan A, Abdelrahman M, Siddique KHM, Tran LSP (2020) Assessment of biochemical and physiological parameters of durum wheat genotypes at the seedling stage during polyethylene glycol-induced water stress. Plant Growth Regul. https://doi.org/10.1007/s10725020-00621-4

57. Pour-Aboughadareh A, Omidi M, Naghavi MR, Etminan A, Mehrabi AA, Poczai P, Bayat H (2019) Effect of water deficit stress on seedling biomass and physio-chemical characteristics in different species of wheat possessing the D genome. Agronomy 9:522. https://doi.org/10.3390/agronomy9090522

58. Qadir M, Quillerou E, Nangia V, Murtaza G, Singh M, Thomas RJ, Drechsel P, Noble AD (2014) Economics of salt-induced land degradation and restoration. Nat Resour Forum 38:282-295. https://doi.org/10.1111/1477-8947.12054

59. Qin J, Dong WY, He KN, Yu Y, Tan GD, Han L, Dong M, Zhang YY, Zhang D, Li AZ, Wang ZI (2010) NaCl salinity-induced changes in water status, ion contents and photosynthetic properties of Shepherdia argentea (Pursh) Nutt. seedlings. Plant Soil Environ 56:325-332. https://doi.org/10.17221/209/2009-PSE

60. Rahnama A, Fakhri S, Meskarbashee M (2019) Root growth and architecture responses of bread wheat cultivars to salinity stress. Agron 111:29912998. https://doi.org/10.2134/agronj2018.12.0795

61. Roy SJ, Negrao S, Tester M (2014) Salt resistant crop plants. Curr Opin Biotechnol 26:115-124. https://doi.org/10.1016/j.copbio.2013.12.004

62. Sadak M (2019) Physiological role of trehalose on enhancing salinity tolerance of wheat plant. Bull Natl Res Cent 43:53. https://doi.org/10.1186/s42269-019-0098-6

63. Sairam RK, Veerabhadra R, Srivastava GC (2002) Differential response of wheat genotypes to long term salinity stress in relation to oxidative stress, antioxidant activity and osmolyte concentration. Plant Sci 163:1037-1046. https://doi.org/10.1016/S0168-9452(02)00278-9

64. Saqib M, Zorb C, Rengel Z, Schubert S (2005) The expression of the endogenous vacuolar $\mathrm{Na}^{+} / \mathrm{H}^{+}$antiporters in roots and shoots correlates positively with the salt resistance of wheat (Triticum aestivum L.). Plant Sci 169:959-965. https://doi.org/10.1016/j.plantsci.2005.07.001

65. Senguttuvel P, Vijayalakshmi C, Thiyagarajan K, Kannanbapu JR, Kota S, Padmavathi G, Geetha S, Sritharan N, Viraktamath BC (2014) Changes in photosynthesis, chlorophyll fluorescence, gas exchange parameters and osmotic potential to salt stress during early seedling stage in rice (Oryza sativa L.). SABRAO J Breed Genet 46:120-135

66. Singh P, Mahajan MM, Singh NK, Kumar D, Kumar K (2020) Physiological and molecular response under salinity stress in bread wheat (Triticum aestivum L.). J Plant Biochem Biot 29:125-133. https://doi.org/10.1007/s13562-019-00521-3

67. Suarez N, Medina E (2008) Salinity effects on leaf ion composition and salt secretion rate in Avicennia germinans (L.) L. Braz J Plant Physiol 20:131-140. http://dx.doi.org/10.1590/S1677-04202008000200005

68. Suriya-Arunroj D, Supapoj N, Toojinda T, Vanavichit A (2004) Relative leaf water content as an efficient method for evaluating rice cultivars for tolerance to salt stress. Science Asia 30:411-415. http://dx.doi.org/10.2306/scienceasia1513-1874.2004.30.411

69. Talukder SK, Babar MA, Vijayalakshmi K, Poland J, Prasad PVV, Bowden R, Fritz A (2014) Mapping QTL for the traits associated with heat tolerance in wheat (Triticum aestivum L.). BMC Genet 15:1-13. https://doi.org/10.1186/s12863-014-0097-4 
70. Xu Y-F, An D-G, Liu D-C, Zhang A-M, Xu H-X, Li B (2012) Mapping QTLs with epistatic effects and QTL× treatment interactions for salt tolerance at seedling stage of wheat. Euphytica 186:233-245. https://doi.org/10.1007/s10681-012-0647-7

71. Zeeshan M, Lu M, Sehar S, Holford P, Wu F (2020) Comparison of biochemical, anatomical, morphological, and physiological responses to salinity stress in wheat and barley genotypes deferring in salinity tolerance. Agronomy 10:127. https://doi.org/10.3390/agronomy10010127

72. Zhu X, Cao Q, Sun L, Yang X, Yang W, Zhang H (2018) Stomatal conductance and morphology of arbuscular mycorrhizal wheat plants response to elevated $\mathrm{CO}_{2}$ and $\mathrm{NaCl}$ stress. Front Plant Sci 9:1363. http://dx.doi.org/10.3389/fpls.2018.01363

73. Zobel RW, Wright MJ, Gauch HG (1998) Statistical analysis of yield trials. Agron J 80:388-393. https://doi.org/10.2134/agronj1988.00021962008000030002x

74. Zou P, Li K, Liu S, He X, Zhang X, Xing R, Li P (2016) Effect of sulfated chitooligosaccharides on wheat seedlings (Triticum aestivum L.) under salt stress. J Agri Food Chem 64:2815-2821. https://doi.org/10.1021/acs.jafc.5b05624

\section{Figures}

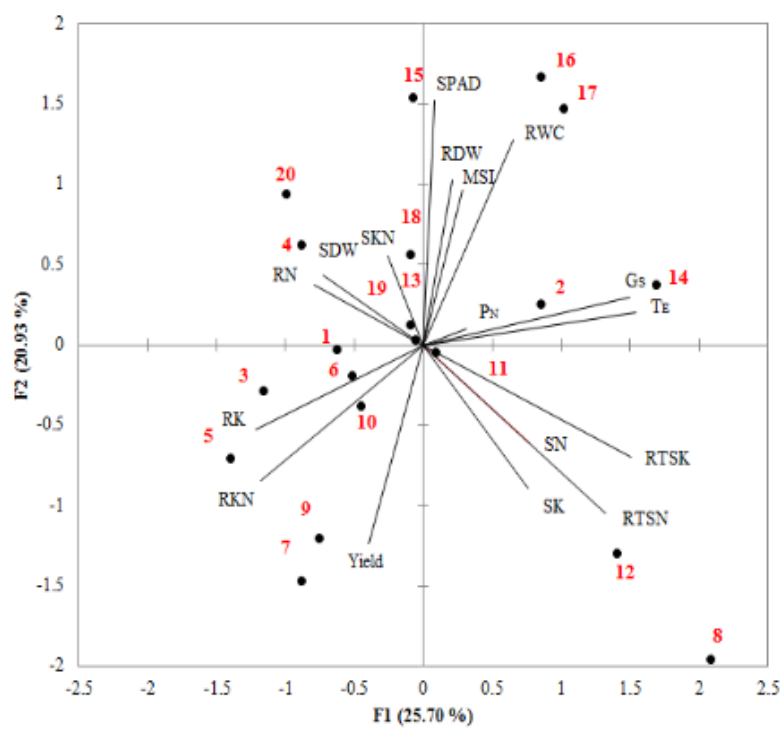

Figure 1

PCA-based biplot of the 16 measured traits at the early-growth stage along with grain-yield performance obtained across four saline regions at the wholeplant stage under salinity stress condition. RDW root dry weight, SDW shoot dry weight, SPAD relative chlorophyll content, PN photosynthetic rate, GS stomatal conductance, TE transpiration rate, MSI membrane stability index, and RWC relative water content, RN root Na+ content, RK root K+ content, SN shoot $\mathrm{Na}+$ content, SK shoot K+ content, RKN root K+/Na+ ratio, SKN shoot K+/Na+ ratio, RTSN root-to-shoot Na+ translocation, RTKN root-to-shoot K+ translocation, YR grain yield. See Table S1 for definition of genotypes.
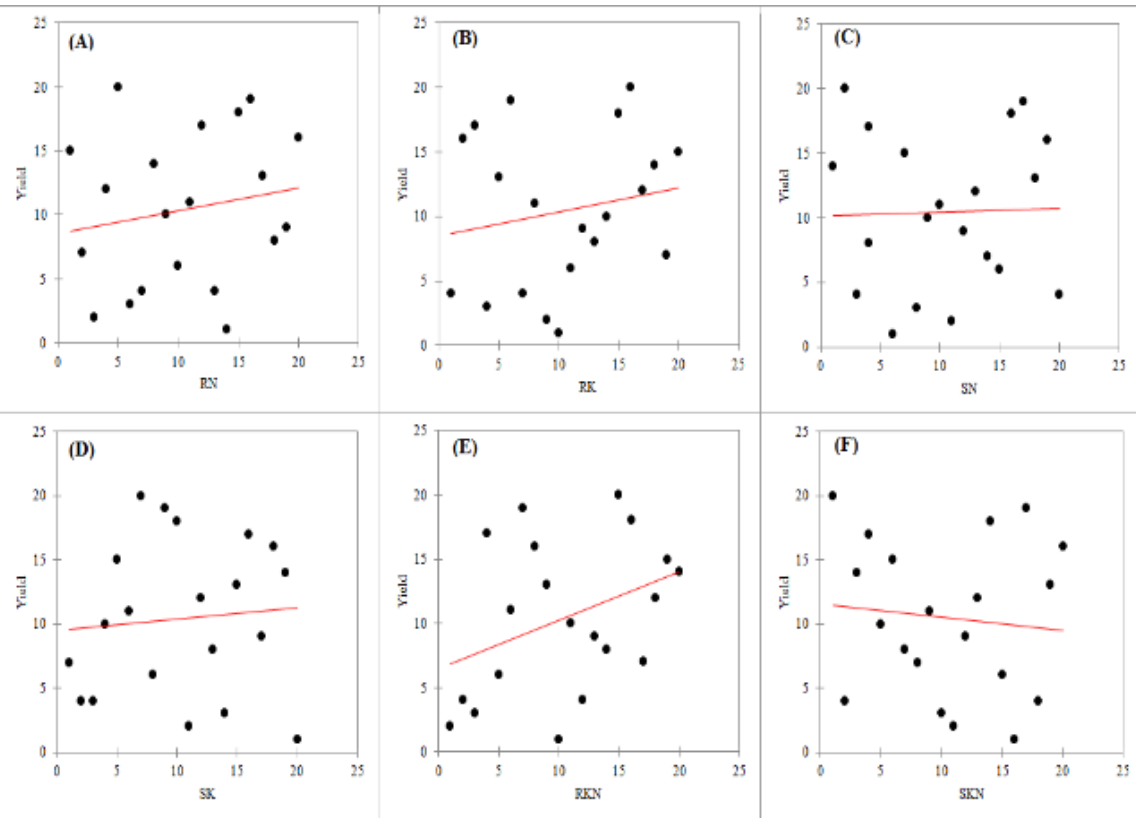

Page $16 / 17$ 
Figure 2

Linear regression between the rank of grain yield and $(A)$ root $\mathrm{Na}+,(B)$ root $\mathrm{K}+,(\mathrm{C})$ shoot $\mathrm{Na}+$, (D) shoot $\mathrm{K}+,(\mathrm{E})$ root $\mathrm{K}+/ \mathrm{Na}+$ ratio, and $(\mathrm{F})$ shoot $\mathrm{K}+/ \mathrm{Na}+$ ratio.

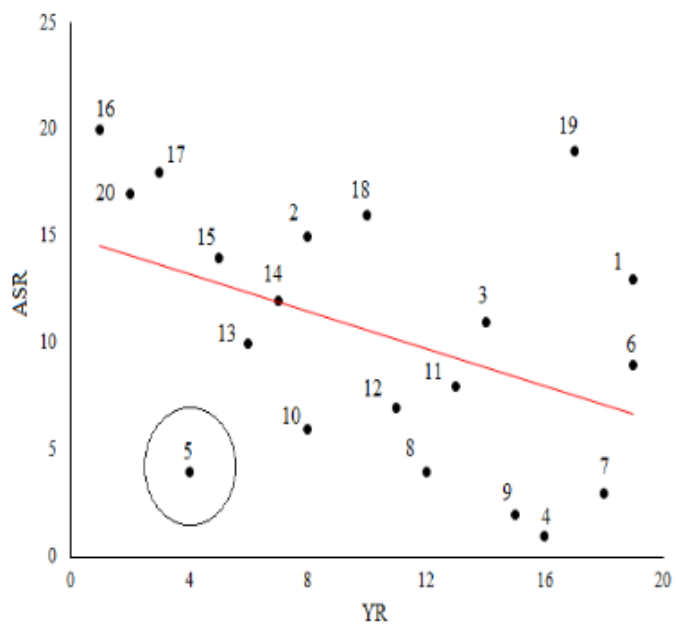

\section{Figure 3}

Relationship between ranking patterns obtained from grain yield and 16 measured traits under salinity stress conditions. See Table S1 for definition of genotypes. The ranking pattern obtained from grain yield is opposite to the ASR method. Thus, the highest grain yield and lowest ASR values have received the minimum and maximum ranks, respectively.

\section{Supplementary Files}

This is a list of supplementary files associated with this preprint. Click to download.

- SupplementrayTables.docx 